УДК 636.8:636.7:612.357.1:619.616.36 - 002

(C) 2014

\author{
Локес П. І., доктор ветеринарних наук, \\ Кравченко С. О., кандидат ветеринарних наук \\ Полтавська державна аграрна академія
}

Локес-Крупка Т. П., аспірант

(Науковий керівник - доктор біологічних наук, професор, академік НААНУ М. І. Цвіліховський) Національний університет біоресурсів і природокористування України

\title{
СТАН ОБМІНУ БІЛІРУБІНУ У СВІЙСЬКИХ СОБАК І КОТІВ ЗА ГЕПАТИТУ
}

\section{Рецензент - доктор ветеринарних наук, професор Б. П. Киричко}

\begin{abstract}
Встановлено, щчо у собак та котів за гепатиту порушується пітментна функція печінки. Відбувається порушення динамічної рівноваги між утворенням, кон'ютацією та виведенням білірубіну. У собак за гострого перебігу гепатиту кількість загального білірубіну підвищена у 5,0, кон'ютованого - у 13,1 разів; більшою мірою порушується виділення кон'югованої форми пітменту. У котів вміст загального білірубіну збільшений у 10,5 разу і в однаковій мірі порушується синтез диглюкуроніду білірубіну та його виведення.
\end{abstract}

Ключові слова: коти, собаки, печінка, гепатит, білірубін.

Постановка проблеми. Хвороби печінки у свійських собак та котів становлять значну частину внутрішньої патології. Однією $з$ найважливіших функцій цього органа $є$ пігментна - поглинання вільної фракції білірубіну, зв'язування його 3 глюкуроновою кислотою та виведення у просвіт жовчних капілярів. Аналіз цієї функції нерідко є вирішальним у диференційній діагностиці захворювань печінки. Між тим, стан обміну білірубіну за патології печінки у свійських собак та котів недостатньо висвітлений у спеціальних публікаціях, тому оприлюднення результатів досліджень у цьому напрямі $є$ актуальним.

Аналіз основних досліджень і публікацій, у яких започатковано розв'язання проблеми. Серед внутрішньої патології собак і котів особливе місце займають хвороби печінки, у тому числі гепатит. Їх вивченню присвячена значна кількість публікацій вітчизняних $[3,4,7,8,11]$ i зарубіжних $[12,14,15]$ дослідників. За даними літератури, захворювання печінки у собак становлять $32 \%$ від усієї кількості хвороб, у

котів, відповідно, $29 \%$ [10]. Залежно від ступеня альтеративних процесів, порушення функції печінки, перебіг гепатиту буває легким, середнім і важким [9].

Печінка - як центральний орган метаболізму виконує багатогранні функції, у тому числі бар'єрну та екскреторну [2]. За гепатиту пору- шуються всі їі функції, у тому числі й білірубінзв'язуюча. Білірубін $є$ токсичним метаболітом, який у печінці знешкоджується шляхом кон'югації. Як наслідок - розвивається синдром жовтяниці, який зумовлений накопиченням у крові білірубіну, жовчних кислот і їх солей.

Мета: вивчити головні ланки порушення динамічної рівноваги між утворенням, кон'югацією i виведенням білірубіну у собак і котів за гепатиту.

Завдання дослідження: дослідити зміни метаболізму білірубіну у собак і котів, хворих на гепатит.

Матеріал і методика досліджень. Роботу проводили на базі кафедри терапії Полтавської державної аграрної академії впродовж 19972013 років. Об'єктом дослідження слугували 50 собак клінічно здорових і 22 хворих і, відповідно, 22 і 10 котів - різних за віком, породою і статтю. Клінічне дослідження тварин проводили за загальноприйнятою схемою. Кров для аналізу відбирали на початку захворювання. Загальний аналіз крові включав підрахунок кількості лейкоцитів (у камері з сіткою Горяєва) та виведення лейкограми (за Філіпченком). Білоксинтезуючу функцію печінки вивчали за рівнем загального білка у сироватці крові (біуретовим методом) та альбумінів (нефелометричним методом). Стан білірубінсинтезуючої функції печінки визначали за вмістом загального та кон'югованого білірубіну методом Єндрашека і Грофа (1939) у модифікації В. І. Левченка і В. В. Влізла [5]. Отримані дані порівнювали 3 показниками клінічно здорових тварин. Статистичну обробку результатів досліджень проводили у програмі Microsoft Exsel 2007. Визначили середню арифметичну (М), статистичну помилку середньої арифметичної (m), вірогідність різниці між арифметичними двох варіаційних рядів з урахуванням t-критерію Стьюдента.

Різницю між двома величинами вважали вірогідною за $\mathrm{p}<0,05 ; \mathrm{p}<0,01 ; \mathrm{p}<0,001$, а також вказували ліміти (Lim) показників. 


\section{ВЕТЕРИНАРНА МЕДИЦИНА}

Результати досліджень. Клінічним дослідженням хворих собак встановлено лихоманку, болючість у ділянці печінки, пригнічення, аноабо гіпорексію, полідипсію (100\% хворих), іктеричність кон'юнктиви та гепатомегалію, виявлених, відповідно, у 90 і $70 \%$ котів та 50 і 68,2\% собак.

Характерними ультрасонографічними змінами $\epsilon$ гепатомегалія, зниження ехогенності паренхіми, потовщення і чітка візуалізація капсули за рівних контурів печінки. Гепатит у більшості тварин супроводжувався сонографічними ознаками холециститу. Типовими для собак і котів $\epsilon$ лейкоцитоз і нейтрофілія 3 регенеративним зрушенням ядра.

У хворих тварин встановлено синдроми функціональної недостатності, холестазу і цитолізу. Синдром функціональної недостатності гепатоцитів характеризується диспротеїнемією, що спричинена гіпоальбумінемією (встановлена у 86,4 \% собак і 79,0 \% котів), позитивною тимоловою пробою, порушенням пігментної функції печінки.

У хворих тварин встановлена іктеричність кон'юнктиви і свербіж шкіри, що характерно для синдрому холестазу. Застій жовчі спричиняє збільшення концентрації жовчних кислот у крові (холемія), які подразнюють рецептори блукаючого нерва, що спричиняє свербіж. За гепатиту в собак i котів порушується обмін білірубіну: у сироватці крові збільшується вміст загального білірубіну та його фракцій (див. табл.). У клінічно здорових собак вміст загального білірубіну становив 2,66,0 ммоль/л $(4,2 \pm 0,14)$, кон'югованого - 0,0-1,5 мкмоль/л $(0,7 \pm 0,06)$. У хворих на гепатит собак кі- лькість загального білірубіну була збільшена у 5,0, кон'югованого - 13,1 разу. Відносна кількість зв'язаного з глюкуроновою кислотою білірубіну за гострого перебігу гепатиту становила 43,6 \%, порівняно $з 16,7 \%$ у здорових собак.

Отже, за гепатиту у собак порушуються всі етапи перетворення білірубіну, проте більшою мірою - екскреція кон'югованої форми внаслідок, очевидно, холестазу, зумовленого зниженням енергетичної можливості уражених гепатоцитів виділяти пігмент у просвіт жовчних капілярів проти градієнта концентрації. Слід також підкреслити, що гіпербілірубінемія встановлена у $100 \%$ хворих на гепатит собак.

Більш виражені порушення пігментної функції печінки в котів. Уміст загального білірубіну у хворих тварин становив 31,0-121,4 мкмоль/л $(60,1 \pm 11,11)$, тобто у 10,5 разу вище за показник клінічно здорових $(5,7 \pm 0,28$ мкмоль/л). Кон'югований білірубін у сироватці крові здорових котів зазвичай відсутній, у хворих на гепатит концентрація сягала $15,6 \pm 1,38$ мкмоль/л, а його частка в загальній кількості білірубіну становила $26,0 \%$. Водночас кількість некон'югованого (вільного) білірубіну за гострого перебігу гепатиту перевищувала у 7,8 разу показник здорових котів $(\mathrm{p}<0,001)$.

Вочевидь, різко виражена білірубінемія є особливістю для патології печінки у котів, оскільки патологічний процес охоплює жовчні протоки 3 розвитком холангіогепатиту i холестазу, який поступово ускладнюється розростанням фіброзної тканини $[6,13]$.

Уміст білірубіну в сироватці крові здорових та хворих на гепатит собак $і$ котів

\begin{tabular}{|c|c|c|c|c|c|c|c|c|}
\hline & \multirow{2}{*}{ Показник } & \multicolumn{3}{|c|}{ Клінічно здорові тварини } & \multicolumn{3}{|c|}{ Хворі тварини } & \multirow{2}{*}{$\mathrm{p}<$} \\
\hline & & $\mathrm{n}$ & Lim & $\mathrm{M} \pm \mathrm{m}$ & $\mathrm{n}$ & Lim & $\mathrm{M} \pm \mathrm{m}$ & \\
\hline \multirow{3}{*}{$\begin{array}{l}5 \\
\text { : } \\
\text { ठँ } \\
0\end{array}$} & $\begin{array}{c}\text { Загальний білірубін, } \\
\text { мкмоль/л }\end{array}$ & 50 & $2,6-6,0$ & $4,2 \pm 0,14$ & 22 & $10,6-25,6$ & $21,1 \pm 0,88$ & 0,001 \\
\hline & $\begin{array}{c}\text { Кон'югований } \\
\text { білірубін, мкмоль/л }\end{array}$ & 50 & $0,0-1,5$ & $0,7 \pm 0,06$ & 22 & $3,7-12,2$ & $9,2 \pm 0,48$ & 0,001 \\
\hline & $\begin{array}{c}\text { Вільний білірубін, } \\
\text { мкмоль/л }\end{array}$ & 50 & $2,4-5,4$ & $3,5 \pm 0,13$ & 22 & $8,2-15,6$ & $12,0 \pm 0,55$ & 0,001 \\
\hline \multirow{3}{*}{ 疍 } & $\begin{array}{c}\text { Загальний білірубін, } \\
\text { мкмоль/л }\end{array}$ & 30 & $4,2-7,2$ & $5,7 \pm 0,18$ & 10 & $31,0-121,4$ & $60,1 \pm 11,11$ & 0,001 \\
\hline & $\begin{array}{c}\text { Кон'югований білі- } \\
\text { рубін, мкмоль/л }\end{array}$ & 30 & 0 & 0 & 10 & $8,3-22,1$ & $15,6 \pm 1,38$ & - \\
\hline & $\begin{array}{c}\text { Вільний білірубін, } \\
\text { мкмоль/л }\end{array}$ & 30 & $4,2-7,2$ & $5,7 \pm 0,18$ & 10 & $12,2-99,3$ & $44,5 \pm 10,46$ & 0,001 \\
\hline
\end{tabular}




\section{ВЕТЕРИНАРНА МЕДИЦИНА}

Отже, за гепатиту в собак і котів розвивається синдром функціональної недостатності печінки, що характеризується гіпоальбумінемією i диспротеїнемією, та холестазу, клінічним проявом якого $є$ іктеричність кон'юнктиви і свербіж, а лабораторним - білірубінемія.

\section{Висновки:}

1. За гепатиту в собак та котів діагностують лихоманку, болючість у ділянці печінки, ано-

\section{БІБЛІОГРАФІЯ}

1. Ветеринарна клінічна біохімія / В. І. Левченко, В. В. Влізло, І. П. Кондрахін [та ін.]; За ред. В. І. Левченка і В. Л. Галяса. - Біла Церква, 2002. $-400 \mathrm{c}$.

2. Ветеринарна клінічна біохімія : Посібник / [М. І. Карташов, О. П. Тимошенко, Д. В. Кібкало [та ін.]; За ред. М. І. Карташова та О. П. Тимошенко. - Харків : Еспада, 2010. - 400 с.

3. Левченко В. I. Поширення множинної внутрішньої патології у собак службових порід та іï патогенез / В. І. Левченко, В. П. Фасоля // Наук.техн. бюлетень Ін-ту біології тварин і Держ. НДКІ вет. препаратів та кормових добавок. Львів, 2008. - Вип. 9, №3. - С. 179-183.

4. Локес П. І. Патологія печінки та органів сечової системи у свійських собак і котів (клінікобіохімічний статус, патогенез, діагностика, лікування): автореф. дис.. ... доктора вет. наук: спец. 16.00.01 «Діагностика i терапія тварин» / П. І. Локес. - К., 2013. - 44 с.

5. Методы ветеринарной клинической лабораторной диагностики : Справочник / Кондрахин И. П., Архипов А. В., Левченко В. И. [и др.]. Под ред. проф. И. П. Кондрахина. - М. : Колос, 2004. - 520 с.

6. Морозенко Д. В. Оксипролін та уронові систоли сечі як діагностичні показники при холангіогепатиті в котів / Д. В. Морозенко // Вет. медицина : Міжвід. темат. наук. зб. ННЦ «IЕКВМ». - Харків, 2010. - Вип. №93. - С. 299-301.

7. Морозенко Д. В. Біохімічні показники стану сполучної тканини у патогенезі, діагностиці та контролі ефективності гепатодистрофії собак / Д. В. Морозенко, О. П. Тимошенко // Біологія або гіпорексію, полідипсію, іктеричність кон'юнктиви, гепатомегалію і свербіж.

2. Типовим показником гепатиту є білірубінемія. Більш інтенсивно зростає рівень білірубіну в котів, у яких в однаковій мірі збільшуються обидві фракції, тобто порушується синтез і екскреція кон'югованого білірубіну, що є характерним для синдромів функціональної недостатності гепатоцитів та холестазу.

тварин (наук.-теорет. журнал). - Львів, 2012. T. 14, №1-2. - $120 \mathrm{c}$.

8. Морозенко Д. В. Біохімічні маркери стану сполучної тканини у патогенезі та контролі ефективності лікування холангіогепатиту котів / Д. В. Морозенко // Вет. медицина: міжвід. темат. наук. зб. ННЦ «ІЕКВМ». - Харків, 2013. - Вип. №97. - С. 335-337.

9. Уша Б. В. Болезни печени собак / Б. В. Уша, И. П. Беляков. - М. : ПАЛЬМАпресс, 2002. - 36 с.

10. Фасоля В. П. Вікова, нозологічна і породна структура хвороб собак у м. Житомирі / В. П. Фасоля // Вісник Білоцерків. держ. аграр. ун-ту - Біла Церква, 2001. - Вип. 28. - С. 256258.

11. Фасоля В. П. Діагностика і лікування гепатопанкреатичного синдрому в собак / В. П. Фасоля // Наук. вісник Львів. нац. ун-ту вет. медицини і біотехнології ім. Гжицького. - Львів, 2008. - T. 10, №2(37). - Ч. 1. - C. 366-372.

12. Favier $R$. $P$. idiopatic hepatitis and cirrhosis in dogs / Vet. Clin. North. Am. Small. Anim. Pract. - 2009. - №39 (3). - P. 481-488.

13. Greiter-Wilke A Association of Helicobacter with cholangiohepatitis in cats / A. Greiter-Wilke, Scanziani E., Soldati S. // Vet. Intern. Med. - 2006. - № 20(4). - P. 22-827.

14. Mandigers $\quad P . J$. Chronic hepatitis in Doberman pinchers / Mandigers P. J., van den Ingh, b. Spee // Vet. Q. - 2004. - 26 (3). - P. 98-106.

15. Poldervaart J. N. Primary hepatitis in dogs: a retrospective review (2002-2006) / J. N. Poldervaart, R. P. Favier, L. C. Penning // J. Vet. Intern. Med. - 2009. - № 23 (1). - P. 72-80. 